\title{
Histological and histochemical study of effects of arsenic on the liver of adult male rabbits
}

\author{
Ibrahim K. Ibrahim \\ Faculty Of Medicine, AL-Azhar University-Assuit
}

\begin{abstract}
Introduction: Arsenic is an environmental toxicant and a human carcinogen. Epidemiology studies link human arsenic exposure to various diseases and cancers, including liver diseases and hepatocellular carcinoma. From this point of view, this study is designed to investigate the effects of arsenic histologically and histochemically on the liver of adult male rabbits.

Material and methods: twenty adult male rabbits were used and divided into four groups. Each group consisted of five rabbits, one group used as a control given an equivalent volume of distilled water and three groups given sodium arsenite in distilled water for 6,12 and 18 weeks respectively. Paraffin sections from all groups prepared and stained by haematoxylin and eosin, and periodic acid-schiff.

Results: histological and histochemical changes in arsenic groups were marked vacuolation of hepatocytes with focal areas of hepatocellular degeneration. Loss of hepatic architecture was also observed. Marked dilatation and congestion of the central veins and mononuclear cellular infiltration were obvious. Quantitative analysis of intracellular glycogen stores of all groups using image analyzing system revealed gradual significant depletion of intracellular glycogen stores.
\end{abstract}

Conclusion: it was concluded that arsenic is a hepatotoxic agent in the adult male rabbits.

\section{Introduction}

Arsenic is a metalloid that occurs naturally in soil, water, and air. Arsenicals are also by-products of production of various metals, as well as coal consumption. A major concern for environmental arsenic exposure and human health is its carcinogenic potential in multiple organs. Arsenic is a human carcinogen, causing cancers of the skin, lung, urinary bladder, and liver (Abernathy et al., 1999; Goering et al., 1999). However, the molecular mechanisms of arsenic toxicity and carcinogenesis are only poorly understood. The liver is a major target organ of inorganic arsenic toxicity. In rats given oral arsenate (20-60 ppm) for up to 6 weeks, swollen mitochondria and altered liver function were evident (Fowler et al., 1977). Hepatic fatty infiltration and degenerative lesions (such as vacuolation) became evident after 12 months of oral exposure of mice to a mixture of arsenite and arsenate, which can progress to liver fibrosis by 15 months (Santra et al., 1997). In mice chronically exposed to arsenite or arsenate via drinking water for 48 weeks, liver parenchymal cell degeneration and fatty infiltration are widespread, with inflammation, focal necrosis and early proliferative lesions (Liu et al., 2000). Hepatocellular proliferative lesions (adenoma and foci of cellular alteration) were increased by repeated arsenate injections in female Swiss mice in a recent 2-year study (Waalkes et al., 2000). Additionally, chronic exposure to arsenite in vitro can cause malignant transformation of rodent liver cells (Zhao et al., 1997). Thus, it is clear that chronic arsenic exposure produces liver toxicity and, possibly, carcinogenicity in rodents, which is consistent with its hepatic effects in humans. Arsenic-induced liver toxicity in humans is, in fact, a common phenomenon. Liver injury induced by arsenic exposure, either from the long-term use of arseniccontaining Fowler's solution in the treatment of psoriasis (Morris et al., 1974; Nevens et al., 1990), or from arsenic 
exposure through contaminated drinking water (Mazumder et al., 1998), food, or air (Liu et al., 1992; Zhou et al., 1993, 1994). Chronic invitro exposure (18 weeks) of rat liver epithelial cells to very low concentrations of sodium arsenite (125 to 500 $\mathrm{nM})$, concentration relevant to environmental arsenic contamination levels, resulted in malignant cellular transformation (Zhao et al., 1997). The gene array analysis of these arsenic transformed cells revealed several important patterns of aberrant gene expression, including altered expression of oncogenes, cell - cycle regulators, signal transduction modulators, stress- and apoptosis- related genes, cytokines, growth factors, and hormone receptors (Chen et al., 2001). Hepatomegaly is the major sign of arsenic-induced liver injury. Serum enzymes (ALT, AST) may be increased or unchanged. Liver toxicity is accompanied by chronic indigestion and abdominal pain, and can progress to liver fibrosis. Cirrhosis, ascites, and hepatocellular carcinoma are the most serious outcome of chronic arsenic-induced hepatotoxicity, and they can often be the cause of death (An et al., 1996; Liu et al., 1992; Zhou et al., 1993, 1998). From this point of view, this study is designed to investigate the effects of arsenic histologically and histochemically on the liver of adult male rabbits.

\section{Material And Methods}

\section{Material:}

In the present study, 20 adult male healthy rabbits weighing 900-1000 gms were used. They were divided into 4 experimental groups (each group consisted of 5 rabbits). The groups were:-

Group I: Control group given an equivalent volume of distilled water.

Group II: Experimental 6 weeks group: drinking distilled water contaminated with sodium arsenite $(500 \mathrm{nM})$, concentration relevant to environmental arsenic contamination level (Zhao et al., 1997).

Group III: Experimental 12 weeks group: drinking distilled water contaminated with sodium arsenite $(500 \mathrm{nM})$.

Group IV: Experimental 18 weeks group: drinking distilled water contaminated with sodium arsenite $(500 \mathrm{nM})$.

\section{Methods:}

The animals were sacrified by decapitation, dissected and the livers extracted. Liver specimens were processed for paraffin sectioning and stained with haematoxylin and eosin stain (H.\&E.) (Drury and Wallington, 1983) to demonstrate the general architecture of the liver and periodic acid-schiff (PAS) (Cook, 1974) to show intracellular glycogen stores.

\section{Quantitative Analysis:-}

All slides were examined after staining by the computerized image analyzer using Optimas 6.2.1 software (Media Cybernetics Inc. 1998). The statistical analysis was carried out according to the standard statistical procedures and Student (t) test to estimate the significance of results using Microsoft Excel 2000.

\section{Results}

\section{Histological results:-}

The liver parenchyma appeared in normal lobular pattern and arrangement including the hepatocytes, hepatic sinusoids and portal tracts. From the central vein plates of hepatic cells radiate towards the periphery. Between the plates, there were the hepatic sinusoids. The plates branched and anastomosed except at the periphery of lobules. The hepatic cells were of polygonal shape, they varied in size, have large rounded vesicular nuclei, which sometimes were binucleated. They had granular acidophilic cytoplasm. There was conge-stion, dilatation of the central vein, congested blood sinusoids and kupffer cells. The hepatocytes showed vacuolar degeneration. There was distortion of the liver architecture, increased hepatic vacuolar degeneration with pyknotic nuclei. Some specimens showed focal area of complete degeneration and cellular infiltration. Most of the hepatic cells showed vacuolar degeneration with pyknotic degenerated nuclei. Some specimens showed complete hepatic cellular degeneration (Plate1: figures $\mathrm{A}-\mathrm{F}$ ).

\section{Histochemical results:}

The PAS positive material was demonstrated as reddish granules in the 
cytoplasm of the hepatocytes. There was mild depletion of glycogen in group II, moderate and massive depletions in groups III and IV respectively. The intracellular glycogen stores in group II $(24.47 \pm 6.74)$ were significantly less than group I (36.48 \pm 2.78$)$. The glycogen stores in group
III (19.52 \pm 7.71$)$ were highly significant lower than group I $(36.48 \pm 2.78)$ and group II $(24.47 \pm 6.74)$. In group IV(12.17 \pm 9.29$)$ glycogen stores were highly significant lower than group I $(36.48 \pm 2.78)$ and group III (19.52 \pm 7.71$)$ (Table 1, Figure 1, Plate2: figures A-D).

Table (1): Mean of intracellular glycogen stores in sections from all groups (Gr. Comp. = groups compared).

\begin{tabular}{|l|c|c|c|c|c|c|}
\hline & Group I & GroupII & \multicolumn{2}{|c|}{ GroupIII } & \multicolumn{2}{c|}{ GroupIV } \\
\hline Mean & $\mathbf{3 6 . 4 8}$ & $\mathbf{2 4 . 4 7}$ & \multicolumn{2}{|c|}{19.52} & \multicolumn{2}{c|}{$\mathbf{1 2 . 1 7}$} \\
\hline STDEV & $\mathbf{2 . 7 8}$ & $\mathbf{6 . 7 4}$ & \multicolumn{2}{|c|}{$\mathbf{7 . 7 1}$} & \multicolumn{2}{c|}{$\mathbf{9 . 2 9}$} \\
\hline Gr.Comp. & & I:II & II:III & I:III & III:IV & I:IV \\
\hline P-Value & & $\mathbf{0 , 0 1}$ & $\mathbf{0 , 0 0 0 1}$ & $\mathbf{0 , 0 0 0 1}$ & $\mathbf{0 , 0 0 0 1}$ & $\mathbf{0 , 0 0 0 1}$ \\
\hline
\end{tabular}

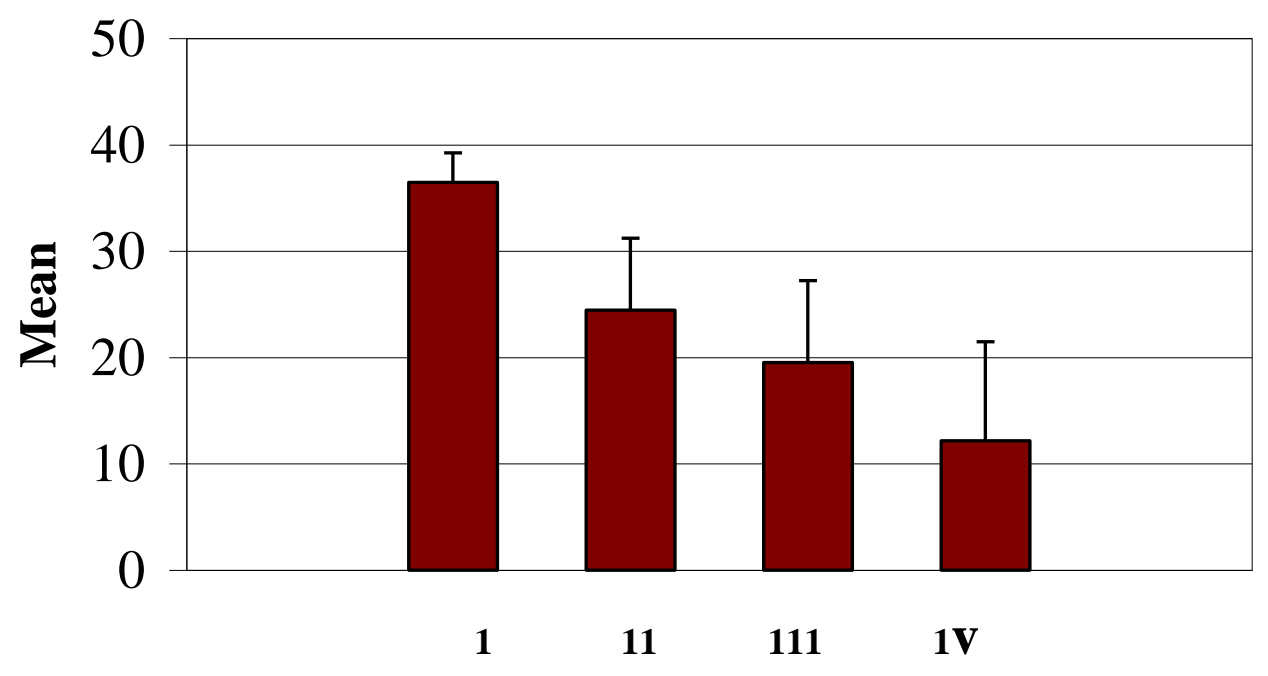

Figure (1): Mean of intracellular glycogen stores. The error bars represent the standard deviation 


\section{Ibrahim K. Ibrahim}

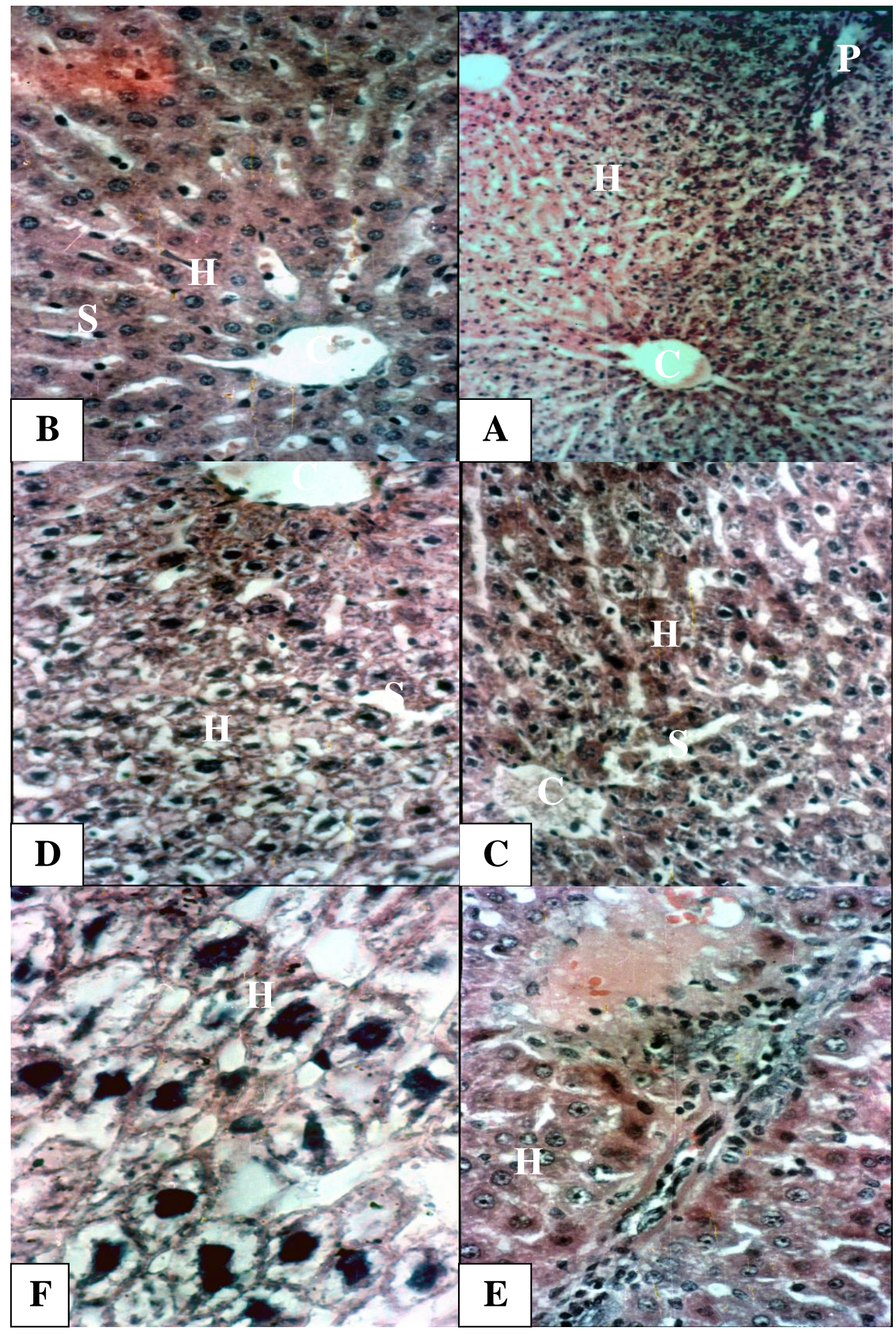

Plate 1: (Liver sections by H.\& E., figure A x200, figures B - E x300, figure F x800). Figures A and $\mathrm{B}$ represent sections from group $\mathrm{I}$, figure $\mathrm{C}$ represent section from group II, figures $\mathrm{D}$ and $\mathrm{E}$ represent sections from group III, figure $\mathrm{F}$ represent section from group IV. Note hepatocytes $(\mathrm{H})$, central vein $(\mathrm{C})$, blood sinusoids $(\mathrm{S})$ and portal tract $(\mathrm{P})$, vacuolar degeneration of hepatocytes as well dilatation and congestion of the central vein and blood sinusoids in figures $\mathrm{C}, \mathrm{D}$ and $\mathrm{F}$, pyknotic nuclei in figures $\mathrm{D}$ and $\mathrm{F}$, focal area of complete degeneration and cellular infiltration in figure $\mathrm{E}$. 


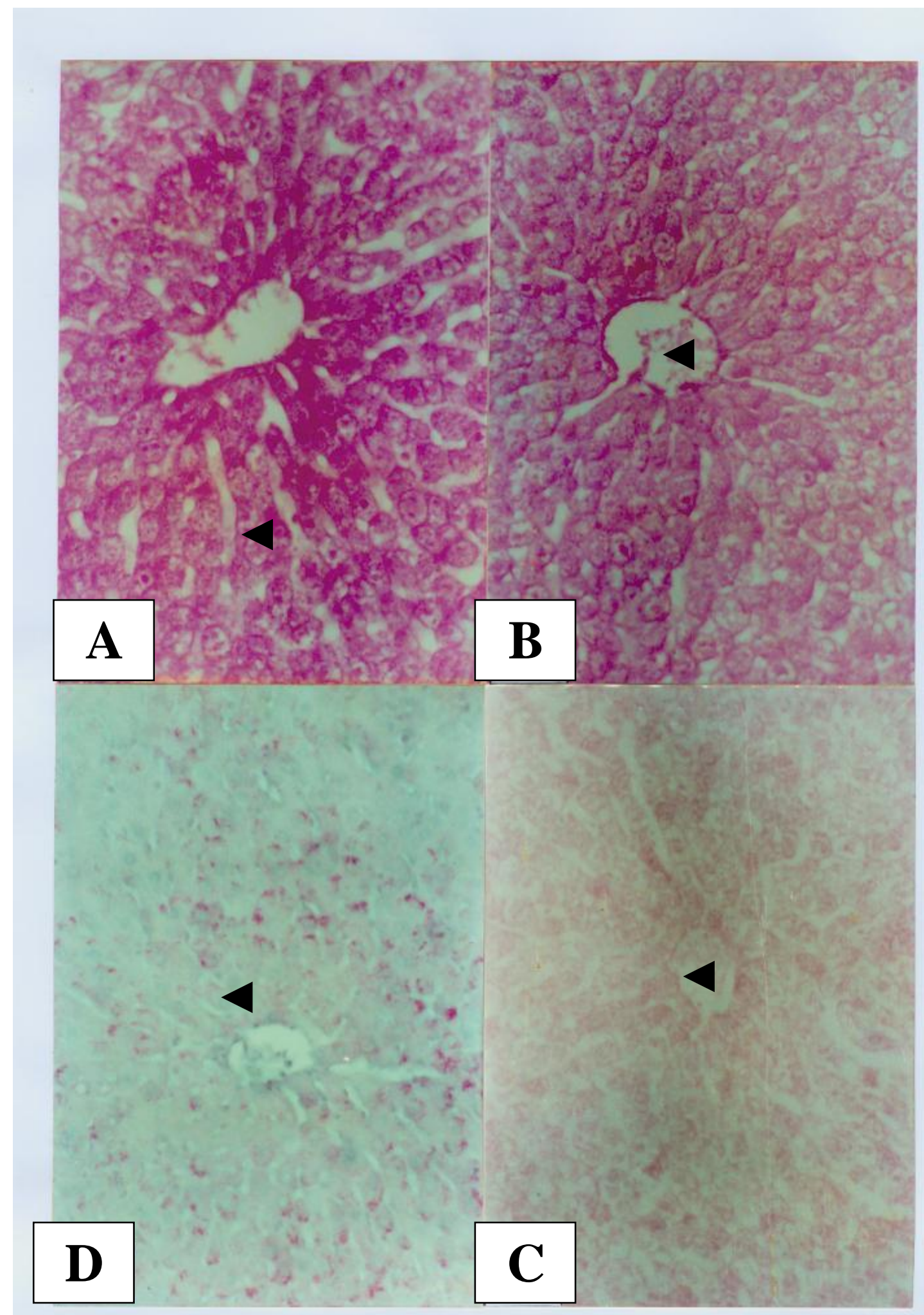

Plate2: (Liver sections by PAS x200), figures A, B, C and D represent sections from groups I, II, III and IV respectively. Note the PAS positive material as reddish granules in the cytoplasm of the hepatocytes (Arrows). Mild depletion of glycogen in group II, moderate and massive depletions in groups III and IV respectively. 


\section{Ibrahim K. Ibrahim}

\section{Discussion And Conclusion}

Arsenic is an environmental toxicant and a human carcinogen. Epidemiology studies link human arsenic exposure to various diseases and cancers, including liver diseases and hepatocellular carcinoma. A variety of gene expression changes may play an integral role in arsenic hepatotoxicity and possibly carcinogenesis. The present study revealed that administration of arsenic produced degenerative changes in the structure of the liver. The histological and histochemical findings were manifested by vacuolation of hepatocytes which was progressed to degeneration of the parenchymal cells, focal area of complete degeneration, deeply stained pyknotic nuclei, disorganized hepatic architecture and dilated congested central veins. In addition to depletion of intracellular glycogen stores. These findings run in full agreement with (Tong Lu et al., 2001). These liver degenerative lesions can be explained by aberrant expression of cytokeratins which constitute a diverse group of intermediate filament proteins expressed as pairs in keratinized and nonkeratinizing epithelial cells (Yu et al., 1993; Wang et al., 1993). Aberrant expression of cytokeratins in liver diseases and hepatocellular carcinomas have been reported. The pair of cytokeratin8 and cytokeratin-18 is known to be liverspecific (Omary \& Ku, 1997). The dilatation and congestion of the hepatic central veins, may be due to arsenicinduced portal hypertension and cirrhosis, which result from overexpression of endothelins and vascular endothelial growth factor B (VEGF-B) seen in arsenictransformed rat liver epithelial cells by (Chen et al., 2001). Endothelins are potent vasoconstrictors and play an important role in increasing intrahepatic vascular resistance, which in turn contributes to portal hypertension in cirrhosis (Petrowsky et al., 1999). The depletion of intracellular glycogen stores may be due to marked induction of cyclin-dependent kinase (CDKN1A) in chronic arsenic-transformed cells (Chen et al., 2001) which plays an important role in glycogen breakdown in hepatocytes. It phosphorylates (activates) a large number of phosphorylase kinase molecules which can activate or catalyzes the phosphorylation of a large number of phosphorylase $b$ molecules to give the $a$ form at the expense of adenosine triphosphate (ATP) (phosphorylation cascade) which in turn leads to marked intracellular depletion of glycogen (Ian, 1988). It can be concluded that arsenic is hepatotoxic. This help to formulate strategies for the treatment and the prevention of arsenic-induced liver injury, and, thereby, to protect human health.

\section{References}

1. Abernathy CO, Liu YP, Longfellow D, Aposhian HV, Beck B, Fowler B, Goyer R, Menzer R, Rossman T, Thompson C and Waalkes $M$ (1999): Arsenic: Health effects, mechanisms of actions, and research issues. Environ. Health Perspect. 107: 593-597.

2. An D, Hu XQ and He GY (1996): Retroperspective study of chronic arsenic poisoning during 30 years in Ba-Zi Village, Guizhou, China. Chin. Public Health 12: 307-308.

3. Chen H, Liu J, Merrick A and Waalkes MP (2001): Genetic events associated with arsenite-induced malignant transformation: Application of cDNA microarray technology. Mol. Carcinog., 665-669

4. Cook HC (1974): Manual Demonstration of Histological Techniques. Butter worths, London, p 139.

5. Drury RAB and Walington EA (1983): Carlton's Histological Techniques, Six ed., Oxford University Press London, 139-142.

6. Fowler BA, Woods JS and Schiller CM (1997): Ultrastructural and biochemical effects of prolonged oral arsenic exposure on liver mitochondria of rats. Environ. Health Perspect. 19: 197-204.

7. Goering PL, Aposhian HV, Mass MJ, Cebrian M, Beck BD and Waalkes MP (1999): The enigma of arsenic carcinogenesis: Role of metabolism. Toxicol. Sci. 49: 5-14.

8. Ian D K Halkerston PhD (1988): formerly, Associate Professor of Biochemistry, University of Massachusetts, Medical Center, Worcester, Massachusetts, Biochemistry, 2 nd edition, by John Wiley \& Sons, Inc.

9. Liu DN, Lu XZ, Li BL, Zhou DX, Li FX. Zheng, DH and Wang KH (1992): 
Clinical analysis of 535 cases of chronic arsenic poisoning from coal burning. Chin. J. Med. 31, 560-562.

10. Mazumder DN, Das Gupta J, Santra A, Pal A, Ghose A and Sarkar S (1998): Chronic arsenic toxicity in West Bengal-the worst calamity in the world. J. Indian Med. Assoc. 96: 4-7, 18.

11. Morris, J.S., Schmid, M., Newman, S., Scheuer, P.J., and Sherlock, S. (1974). Arsenic and non-cirrhotic portal hypertension. Gastroenterology 66: 86-94.

12. Nevens F, Fevery J, Van Steenbergan W Sciot R, Desmet $V$ and De Groot J (1990): Arsenic and non-cirrhotic portal hypertension. A report of eight cases. $J$. Hepatol. 11: 80-85.

13. Omary M B and Ku NO (1997): Intermediate filament proteins of the liver: Emerging disease association and functions. Hepatology 25: 1043-1048.

14. Parrish A R, Zheng X H, Turney K D, Younis H S and Gandolfi A J (1999): Enhanced transcription factor DNA binding and gene expression induced by arsenite or arsenate in renal slices. Toxicol. Sci. 50: 98105.

15. Petrowsky H, Schmandra T, Lorey T, Hanisch E and Herrmann G (1999): Endothelin-induced contraction of the portal vein in cirrhosis. Eur. Surg. Res. 31, 289-296.

16. Santra A, Maity A and Mazumder DNG (1997): The mechanism of liver damage due to chronic feeding of arseniccontaminated water in mice. In Arsenic Health Effects Symposium, abstract \# 9. Hunt Valley, MD.

17. Tong Lu, Jie Liu, Edward L. LeCluyse, Ming-Liang Cheng and Michael $P$.
Waalkes: Application of cDNA Microarray to the Study of Arsenic-Induced Liver Diseases in the Population of Guizhou, China. Toxicological Sciences 59: 185-192 (2001).

18. Wang L F, Liu H D and Lin F F (1993): Endemic arsenism in a village of Xinjiang: Epidemiological, clinical, and preventive studies for 9 years. Endemic Diseases Bulletin 8: 71-79.

19. Yu H S, Chiou KS, Chen G S, Yang R C and Chang $S$ F (1993): Progressive alterations of cytokeratin expressions in the process of chronic arsenism. J. Dermatol. 20: 741-745.

20. Zhao CQ, Young MR, Diwan BA, Coogan TP and Waalkes MP (1997): Association of arsenic-induced malignant transformation with DNA hypomethylation and aberrant gene expression. Proc. Natl. Acad. Sci. U.S.A. 94: 10907-10912.

21. Zhou DX (1993): Investigation of chronic arsenic poisoning caused by high-arsenic coal pollution. Chin. J. Prevent. Med. 27: 147-150.

22. Zhou YS, Zhou DX, Zheng BS, Yang DQ, Luo ML, Zhang HT, Jin DX, Peng J H, Fan J, Chen J, Hong $L$ and Zhou Y (1998): Epidemiological investigation on coal-burning type of arsenic poisoning in different environments within 20 years. Chin. J. Endemic Dis. 17: 1-4.

23. Zhou YS, Zhou DX, Zhu SL, Jin DX, Peng JH and Huang SQ (1994): Investigation of arsenic content in food dried by normal coal and high arseniccontaining coal. Chin. Public Health 10: 77-79. 


\section{دراسة هيستولوجية وهيستوكميائية لتأ ثيرات الأرسينيك على كبد ذكور الأرانب البا لغة النة}

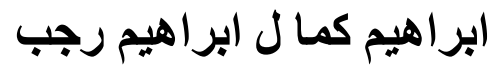

قسم الهيستولوجى- كلية الطب- جامعة الأز هر - أسيوط

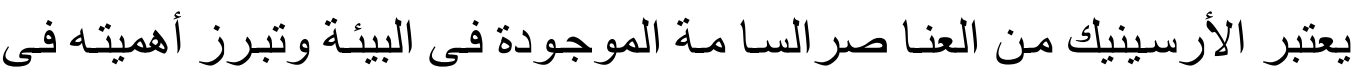

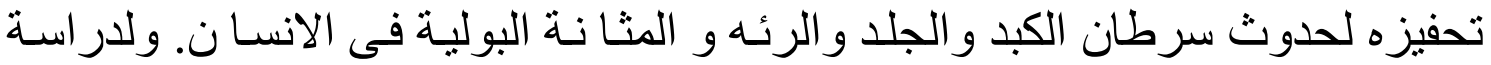

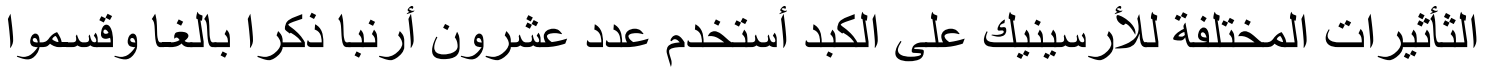

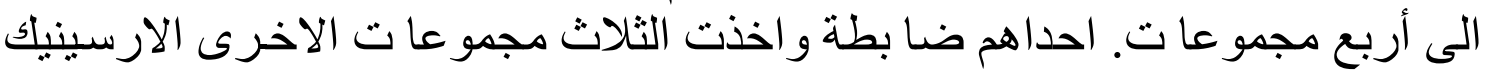

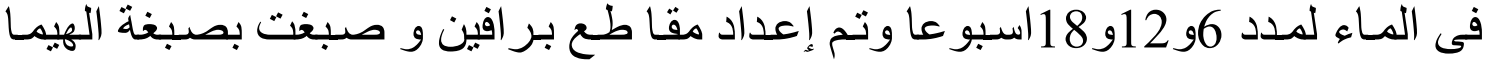

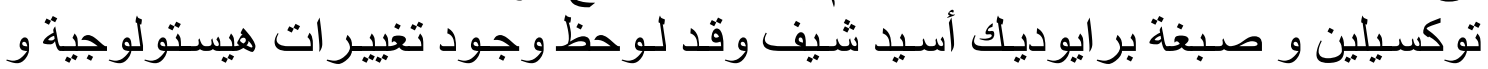

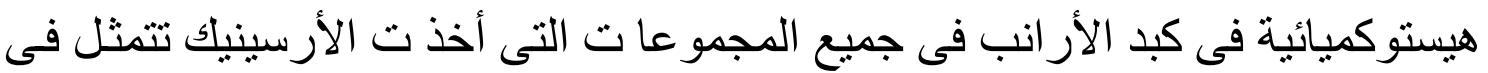

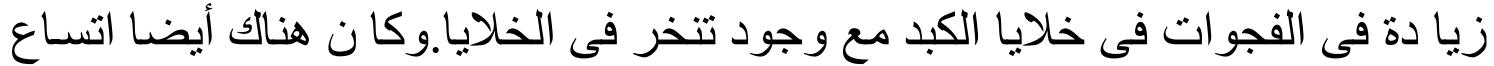

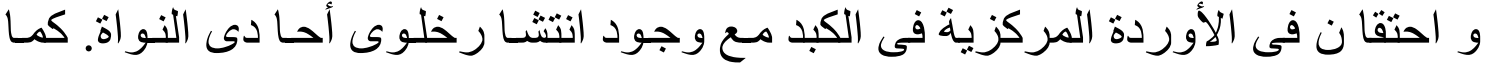

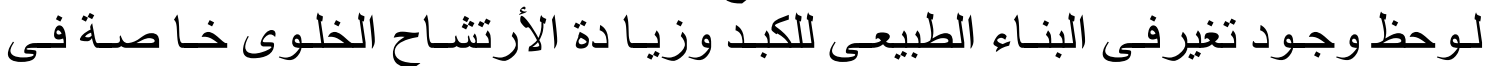

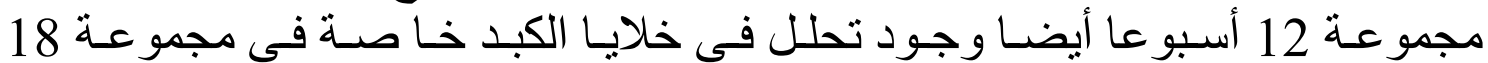
أسبو عا. ولقد لوحظ وجود نقص تدريجى فى كمية الجليكوجين المختزن حيث ظهر هذا

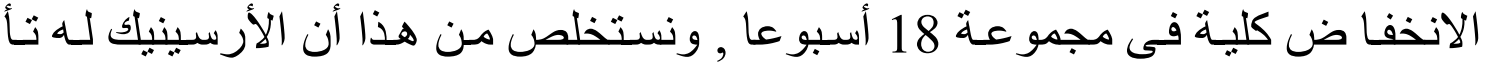
ثير ات سا مه على الكبد في ذكور الأرانب البالغه. 